\title{
IS CHINA CATCHING UP? TECHNOLOGICAL SOPHISTICATION OF CHINESE EXPORTS TO EUROPEAN UNION
}

\author{
Jana Vlčková*
}

\section{Introduction}

Rising technological and innovative capabilities in some emerging economies, especially in China, have attracted a lot of attention since these economies are starting to challenge the capabilities of the historic R\&D leaders. Chinese products have conquered world markets and China is called the workshop of the world. The current view on China reminds the fears of Japan in the 1970s and 1980s. The question is whether the technological capabilities in China are rising significantly and can be a threat to the economic position of developed countries.

The US share in the world's science and engineering graduates is declining rapidly (Freeman, 2005) and the situation is similar in Europe. Furthermore, the productivity gap between the US and Japan on the one hand and Europe on the other hand is widening. Fiscal problems in Europe may restrict investment for several years and thereby higher divergence among EU countries is expected in this decade. Thus, the share of R\&D and innovations among the developed regions of the world is expected to decrease most significantly in the EU.

The views on whether emerging economies will be able to catch up with developed regions in innovation capabilities differ. Despite the huge investment in R\&D, rising numbers of graduates in science and technology fields and rising share of scientific papers, the share in triadic patent families is still very low in China. The aim of this paper is to find out whether China is catching up with other developed countries in terms of technology and innovations.

There are various methods used for measuring the innovative capacity of an economy, although measuring of technology and innovations as such remains problematic. One of the possibilities is to measure the technological capabilities of countries based on the technological sophistication of their exports. The technological level of Chinese exports - the EXPY introduced by Hausmann et al. (2007) will be used in this paper. This index is calculated for each country importing goods to the EU12 and

* University of Economics, Prague, Faculty of International Relations (xnovj75@vse.cz).

This article was supported by the IGA project Politics of the European Union: plans and changes in the background of the Lisbon Treaty No. F2/24/2010. 
is based on the assumption that high-income countries export commodities which are associated with higher productivity.

The EXPY calculation is based on products imported to the EU12 from all countries in the years 1990, 1995, 2000, 2005 and 2009 using the Eurostat trade data. EU had only 12 member states in 1990 and the Eurostat offers only data for its members, therefore all the calculations were made for the EU12 because changing the number of countries could alter the results. Hausmann et al. (2007) used detailed product classification; only 68 product groups (two-digit SITC codes) were used in my calculations because this paper is a preliminary study to a more detailed analysis.

\section{Technology, globalisation and trade}

In the 1980s, scholars started to regard technology, innovations and R\&D as key drivers to economic performance (Aghion and Howitt, 1992; Baumol et al., 1989). This is in big contrast to earlier years when technology was regarded as an exogenous factor to economic growth (the Solow residual). Globalisation has brought increasing competition and the pressure on firms to innovate is higher than ever before. New technology, $\mathrm{R} \& \mathrm{D}$ and innovations are important without any doubt. The question is what type of innovations/technology is crucial? First, a distinction between specific terms should be made.

Based on OECD definitions "innovation is the implementation of a new or significantly improved product (good or service), or process, a new marketing method, or a new organisational method in business practices, workplace organisation or external relations" (OECD, 2005, p. 46). There is often a mutual interdependence between technological and organisational innovations.

Research and development (R\&D) refers to creative work "undertaken on a systematic basis in order to increase the stock of knowledge, including knowledge of man, culture and society, and the use of this stock of knowledge to devise new applications" (OECD, 2002, p. 30). There are huge differences in R\&D investment between industries; many industries in the service sector are not engaged in any systematic $\mathrm{R} \& \mathrm{D}$, though they do innovate.

Technology is the state of knowledge concerning ways of converting resources into outputs (OECD, 2001). Rosenberg (1982, p. 3) defines it as "a certain type of knowledge which makes it possible to produce (1) a greater volume of input or (2) a qualitatively superior output from a given amount of resources”. Technological upgrading refers to the movement from low-value to relatively high-value activities.

Diffusion is the process within which innovations and new knowledge spread through the society. Diffusion is critical for the economic impact of an invention and it relates to the size of the cost reduction that it makes possible by comparing the new technology to the alternative available technology. The rate and speed of diffusion in a country depend on its environmental and institutional conditions.

New technology is often stressed as a key determinant of economic growth, especially in the "new" growth theories (Romer, 1991; Aghion and Howitt, 1992, etc.). 
Many authors (e.g., Schumpeter, 1947) think of the nature of technological change as discontinuous. However, Rosenberg (1982) notes that the process of innovation-implementation and small improvements and modifications can be as important (or even more important) as infrequent major innovations and there is a big variety in utilization of technological innovations developed in other industries. At the same time, new technology can lead to the decline of some older technology as a part of the processes of creative destruction. Many industrial areas have come down because they were locked-in in declining industries.

Many concepts aim at supporting innovation in countries and regions and its diffusion. Innovations and new technology are generated in areas with high rates of capital accumulation and specific human capital. Tacit knowledge ${ }^{1}$ as well as formal and informal institutions are considered to be the key determinants of the geography of localisation activity. Thus, proximity plays a crucial role even in the Internet age (Gertler, 2007; Lundvall, 1992). Many empirical studies have proven the importance of local context (Saxenian, 1996). Historical processes do matter; hence, we should not forget the path-dependent nature of the innovation process. Even though innovations remain concentrated in a few areas, radical innovations can create "windows of locational opportunity", where physical and labour capital crucial for existing industries is of little relevance (Scott and Storper in Storper, 2011).

Innovation and technology originate in a few regions and spread to other regions thanks to diffusion. Typically, the diffusion in the adoption levels within technology across countries is about 5 times larger than the cross-country diffusion in income per capita (Comin et al., 2006) and thus "technology transfer keeps countries from drifting indefinitely far from each other” (Hall and Jones, 1999, p. 4).

\subsection{Globalisation and technology}

Globalisation has brought qualitative differences; global economy is increasingly interconnected and thus more volatile. Productive activities have been decomposed and the whole production process vertically disintegrated. Different types of activities are located in different parts of the world. New interdependencies between firms, industries and nations are being established.

When speaking about new interconnections, the global production network concept can help explain them. A global production network (GPN)2 "is the circuit of interconnected functions, operations and transactions through which specific commodity, good or service are produced and consumed" (Dicken, 2011, p. 56). GPN have a huge impact on innovation capabilities of a country, they can stimulate diffusion of innovations or

1 Tacit knowledge is specific knowledge that is difficult to transfer because (1) people are often not aware of the fact they have the knowledge; (2) it is difficult to express the knowledge (Gertler, 2007).

2 Apart from GPN, global value chains (GVC) and global commodity chains (GCC) are other common concepts. The GPN approach is broader; GVC/GCC concentrate on linear structures and inter-firm relations, whereas GPN encompass all kinds of networks, actors and relationships (Coe et al., 2008). 
vice versa. This depends especially on the position of the country and its enterprises in the GPN (Altenburgh et al., 2008).

Thanks to GPN, parts of the products can be produced in various countries and then assembled. When imported inputs are used to assemble a final product, the share of value added generated by the exporting country is much lower than appears at first sight. A common example is the iPod, which is assembled in China and exported to the USA for USD 150, whereas the value added in China is around USD 4; the remaining value is attributable to other countries such as the USA and Japan (Koopman et al., 2008). Hummels et al. (2001) proposed a calculation of "vertical specialization" of a country's trade, which measures foreign value added embodied in exports based on an input-output table.

Processing exports are goods produced by assembling intermediate inputs, which are exempted from tariffs since the final products are sold only on foreign markets. According to Koopman et al. (2008), processing exports account for more than 50\% of China's exports (twice as high as estimated by the calculation of vertical specialisation). They also found that in goods that are more sophisticated the share of domestic content is even lower and vice versa for low-skilled products.

Production is not the only activity that has been relocated to some measure. Internationalisation of R\&D has followed manufacturing and services but it remains limited. However, the trend is clear: a growing share of R\&D is undertaken abroad (UNCTAD, 2005). Only a decade ago, a research by Patel and Pavitt (1991) showed that based on the geographical distribution of patents of the world's largest firms, innovative activities were among the least internationalized of their functions. Many studies show that knowledge spillover is a geographically localised process (Jaffe et al., 1993). Surprisingly, the present-day geographic dispersion of the innovation process does not contradict these studies: it remains concentrated in the old as well as a handful of new clusters. Strategic alliances in R\&D and open innovation are now more common. The total share of patents involving international co-invention worldwide increased from $4 \%$ in 1991-93 to 7\% in 2001-03 (OECD, 2009). Many emerging economies form collaborations with other global leaders to build their scientific and technological infrastructure and knowledge base.

Nevertheless, it is difficult and costly to fragment R\&D in different parts of the world. Knowledge is cumulative and consists of codified as well as tacit knowledge. There is a high demand for organisational and managerial skills and a risk of technology leakage - especially in countries with weak intellectual property rights (IPR) protection like China - reduces the offshoring of $R \& D$. On the other hand, lower costs and search for new talents are the main reasons for R\&D offshoring. While offshoring of $R \& D$ to some emerging economies is important, it is not the only source of $R \& D$. Emerging economies develop their own innovation capabilities in both the public and private sectors. Furthermore, we also witness flows of R\&D from emerging economies to developed countries and within emerging economies themselves.

Apart from production networks, personal and professional networks are another factor that can contribute to technological upgrading. According to Saxenian (2007), the growing mobility of highly skilled workers makes the flows two-way and it is 
more a "brain circulation" than a "brain drain". She argues that Chinese scientists and entrepreneurs with experience from Silicon Valley can transfer knowledge and skills between distant regions more efficiently than TNCs.

Globalisation can enable some countries to catch up but, on the other hand, division of labour allows developed countries to focus on non-routine activities with high value added since standardized production takes place in developing countries.

\subsection{China}

China is trying to become a technology leader ${ }^{3}$. Its economic growth which started in the 1980s is impressive. Unlike other countries, China has not been hit hard by the recent financial crisis. Foreign investment has played a major role in China's growth. The FDI helped to foster domestic capacities thanks to policies that ensured technology transfer. Reverse engineering and imitation is common in China because of weak enforcement of IPR. Various conflicting policies aimed at supporting innovations and technology have resulted in many different regional systems. These systems excel in perfecting innovation capabilities used in production and adaption of products developed elsewhere (Bresnitz and Murphree, 2011).

The big advantages of China are its huge and rising market size, attractiveness for FDI and capital accumulation enabling huge investment in the innovation system. The GDP growth pace has been about $10 \%$ in the last 20 years; however, the big question is its sustainability. China has great international professional networks and has started reverse brain drain policies to attract Chinese scientists back home. Another advantage is its economic purchasing and political bargaining power. China's high-tech design and manufacturing abilities are growing in many fields neglected by developed countries (material science, etc.).

Trade has played a significant role in China's transformation and intensified after its WTO entry. China is able to offer flexible production on a mass scale although rising wages may reduce its cost advantage. China's huge economic growth is even more surprising when we consider that China has opened gradually, it still has not accomplished many important reforms, and the rule of law remains weak. Similar to other East Asian countries, China has followed policies of promotion and protection (Rodrik, 2006).

There are two opposite opinions on whether China can become a technology leader. Some authors are convinced that it is already happening (Segal, 2003; Porter et al., 2009), whereas others believe that China does not have the capability to come up with breakthrough innovations (Cao, 2004; OECD, 2006). Bresnitz and Murphree (2011) present a different view. They argue that China can excel without creating novel technologies. Japan did the same when it gained dominance in the car industry by developing a superior production system rather than novel-product innovations.

3 China has an ambition to become an innovation-oriented country by 2020 (Chinese Government Official Web Portal, 2006) 
So far, China has made big progress in R\&D and innovations mainly in input factors: in R\&D investment and employment. Output indicators such as patents and scientific publications remain weak, although the catch-up in science is faster than in technological innovation ${ }^{4}$. The question is whether the difference between the effort and the achievement is caused by inefficiencies in the innovation system or due to the time lag between the R\&D investment and output. The numbers of graduates are also rising dramatically. Apart from a few universities, the quality of the graduates is rather poor, however. Based on a McKinsey report (2005), only 10 percent of China's engineering graduates are suitable for work in global corporations. Nevertheless, the supply of well-trained engineers from China is considerable.

China is a top supplier of manufacturing outsourcing for many global companies. The majority of foreign-invested enterprises engage in manufacturing activities and perform little R\&D in China (OECD, 2009). If TNCs perform R\&D, it is mostly adaptive R\&D or innovative R\&D linked to production for the local market. China's trade in high-tech products is still dominated by processing with imported materials, and processing and assembly is still the main source of China's high-tech exports (OECD, 2009). Process innovations and incremental improvements prevail in China. On the other hand, China's high-tech companies create a reverse flow of R\&D investments to the advanced nations. Chinese companies such as Huawei are going global and they can also acquire technology knowledge through industrial acquisitions.

China's export structure is upgrading but is it due to rising technological and innovation capabilities or rather due to the assembly of sophisticated final goods from imported sophisticated intermediate inputs? China is labour-abundant although there are huge regional differences ${ }^{5}$. Even the position of Chinese high-tech regions (Beijing, Shanghai-Suzhou and Shenzen-Dongguan) in the GPN differs and they perform different functions for the domestic market (Zhou et al., 2011). Thus, the evaluation of China's performance is more complicated.

There are three possible scenarios for China in the field of technology and innovations: China will become a technology leader; China's position will improve but China will not surpass the position of developed countries; or China's position will decline because of political or/and environmental reasons. A mixture of government policies has helped foster China's innovation capabilities (Bresnitz and Murphree, 2011). Whether China's policies will remain flexible in future is thus of key importance.

4 The share in triadic patent families in 2008 was only $1.1 \%$ and China accounted for $12 \%$ of the world's scientific articles (OECD, 2010).

5 The GDP per capita in Shanghai Municipality was 12 times higher than in Guizhou Province in 2000 (Schott, 2008). 


\subsection{Measuring technology and innovations}

Without any doubt, Chinese products have flooded the world. This paper focuses on whether China is catching up ${ }^{6}$ with developed countries in technology, innovations and R\&D. One of the biggest problems of comparing technological sophistication and innovation capability of nations, regions and even firms is how to measure it. As Alteburg et al. (2008) noted, "it is notoriously difficult to measure and compare innovation capabilities.” Technology and innovations embodied in physical equipment, goods and services, and organizational forms are difficult to observe or measure.

There are several indicators used for measuring innovations. One of them is total factor productivity, which accounts for effects in total output not caused by capital and labour inputs. However, there are other factors besides technology, which are a part of the Solow residual and the question how to distinguish technology has not been solved. Furthermore, technology is correlated with capital. Inputs and outputs of scientific activity such as patents, R\&D expenditures, human capital and scientific publications or citations are among other common indicators. Their use has many limitations. Regarding patents, not all things are patentable and there are differences in patenting between industries and countries. Most patents are worth very little. In the case of R\&D expenditures, the returns from public and private expenditures can differ significantly. The time lag for the effect of R\&D activities on productivity is not known (Griliches, 1979). Many innovations especially in the service sector do not come from any formal R\&D.

Trade data are used as a measure of China's innovation capability because they are among the most reliable (in manufacturing, not in services) compared to data on innovations and R\&D. Therefore, trade data will be used as a measure of technological sophistication in this paper.

\subsection{Trade}

The specialisation of a country on particular products and tasks is determined by its "resources" - physical and human capital, labour, natural resources and the quality of its institutions. Thanks to international trade, countries can specialise on products that they are best at. In the Ricardian model of comparative advantage, specialisation is a consequence of differences in labour productivity across industries and is caused by using different technologies. The Hecksher-Ohlin model removes technology variations and is based on the factor endowments of a trading region. According to the Hecksher-Ohlin model, countries will use intensively the factor of production which is relatively abundant in the country and import products which use the country's scarce factors. Trade barriers and trade policies promoting exports are not included in these models and can act against them. International trade takes place between high-income and low-income countries, as well as between two high-income countries, therefore

6 In this sense the term 'catch up' means technology and innovations embodied in machinery and products, methods and processes used in business practices and organisation, as well as progress in R\&D mostly in basic research. 
new trade theory models stress consumer habits such as their love of variety and market size as well (Schott, 2008).

Many other forces shape the type of products that countries export - uncertainty of entering into new activities, technological spillover, network effects, increasing returns to scale, etc. In general, "countries that specialize in the types of goods that rich countries export are likely to grow faster than countries that specialize in other goods" (Hausmann et al., 2006, p. 2). Rich countries usually export goods which are associated with higher productivity. I will be using indexes called PRODY and EXPY proposed by Hausmann et al. (2007), which are based on products that countries export. Exports of countries are a good proxy showing the ability of a country to produce competitively for the world markets. Goods of poor quality, not good enough for the exports, can be still traded within the economy.

\section{Methods}

The EXPY index for all countries exporting goods to the EU (see Hausmann et al., 2007) is calculated based on the trade data. In the first step, the PRODY index is calculated which assigns productivity scores to all traded products based on the weighted average of comparative advantages of its exporters' incomes. Then, the EXPY is calculated based on the PRODY scores for the goods and its relative representation in the exports to the EU12.

$\mathrm{Xu}$ (2006) constructed the QEXPY index when he added to the PRODY an index which measures the relative unit value of a country's exported goods in order to cover products of different quality within the same product group. Kemeny (2011) calculated a similar index - TECH. It also includes the quality level of each good based on relative unit prices and, in addition, it accounts for changes in the sophistication of products themselves over time. The TECH index is highly correlated with both EXPY and QEXPY (Kemeny, 2011).

For each product, a weighted average of the per capita GDP (in PPP) of the countries that export the product is calculated - the PRODY index. It defines the revealed productivity associated with an individual good. After that, another index - EXPY - is calculated for each country based on the export-weighted average of the PRODY. Hausmann et al. (2007) constructed a time-invariant PRODY indicator. I am using a measure of revealed productivity proposed by Kemeny (2011), which varies by product and year (but not by country). Using a calculation for several years enables us to observe the time variation. Unlike Kemeny (2011), I do not use the unit price differences. Firstly, the indexes with price units are highly correlated with the EXPY, so using EXPY at this stage of research should be sufficient. Secondly, the Eurostat data do not capture the quantity of goods (only in some cases), which makes this calculation impossible.

Let countries be indexed by $c$ and goods by $g$; $X_{c}$ denotes total exports by a country, $x_{c g}$ is the value of a good $g$ for a country $c$, and $Y_{c}$ is the per capita GDP in PPP for a country. Hence, 


$$
P R O D Y_{g}=\sum_{c}\left(\frac{\frac{X_{c g}}{X_{c}}}{\sum_{c}\left(\frac{X_{c g}}{X_{c}}\right)}\right) Y_{c},
$$

where the numerator is the value of the good $g$ as a share of the total value of exports for the country $c$, the denominator aggregates the value shares of all the exporters of the good $g$. The productivity level for each country (EXPY) is a weighted average of the PRODY:

$$
E X P Y_{c}=\sum_{c}\left(\frac{x_{c g}}{X_{c}}\right) P R O D Y_{g},
$$

where the weights are the value shares of the products in the country's total exports.

\subsection{Data}

The trade data are from the Eurostat trade statistics; imports of services were excluded ${ }^{7}$. The imports from individual countries to the EU12 do not distinguish processing exports $^{8}$. The two-digit SITC codes are used for product classification (overall 68 product classes). Hausmann et al. (2007) and Kemeny (2011) used a more detailed product classification (at least 6 digits). Using as many product classes requires more complicated calculations. Since this is only a preliminary study, only two-digit-level classification was used. In further research, the calculations will be based on more detailed data. The value of the exports is measured in Euros.

The EXPY was calculated for the years 1990, 1995, 2000, 2005, and 2009. Only imports to the member states of the EU12 were considered because in 1990 only these 12 member states were in the EU and the Eurostat offers only data for them. On account of EU enlargement, another 15 states became members of the EU during the observed period. Increasing the number of the states whose imports were evaluated could markedly change the calculation of the EXPY. For that reason all the calculations are based on imports to the EU12.

The wealth of the countries is based on the GDP per capita in PPP. Using simply exchange rates may distort the real differences in income. Purchasing power parity is more useful when comparing generalized differences in living standards between countries. The data come from the Penn World Tables (Heston et al., 2011).

All the imports to countries of the EU12 were included; trade within the EU12 states was not taken into account. Observations for islands which are part of other countries were also given in the Eurostat data. Where these islands were part

7 The data on the quality of the trade in services is considerably lower than for manufacturing. Countries exporting more advanced services are expected to export more sophisticated goods.

8 Data for processing exports require using input-output tables which are available only for some countries and some years. 
of the EU12 states, their imports were excluded. Where islands were part of non-member states, their imports were added up to the imports of their respective countries.

Thenumber of countriesintheobservedperiodincreased, mainlybecauseofthebreakdown of former USSR and Yugoslavia. The calculations for each year are based on countries which were independent at that time. Non-specified countries, polar areas and stores were excluded from the source data. Confidential products were also excluded.

Hausmann et al. (2007), Kemeny (2011), and Xu (2006) used imports to the US. The US economy is big, relatively open and it is an attractive export destination. On the other hand, the EU12 consists of 12 countries and many EU policies can alter the exports. Other things can alter the imports like differences in demand, customer habits and transport costs. The USA is rather "isolated"; the EU is surrounded by many states. A lot of them became member states of the EU during the observed period and thus also part of the EU internal market. Although the US seems to be a better unit for classifying the export sophistication of countries, the author is interested mainly in China catching up with the EU and therefore using exports to the EU is understandable. Furthermore, counting the EXPY on EU data will enable us to find out whether there are considerable differences in the results for the EU and the limitations of using this type of data.

\subsection{Results}

The EXPY index is calculated based on imports to the member states of the EU12. The value of import shares of countries have changed dramatically, as well as the type of goods being exported, and these alter the calculations. China's exports to the EU12 have risen six times, confirming it as the workshop of the world (see Table 1). The US exports have fallen by $40 \%$ and Japanese by $60 \%$. Two post-communist countries, Poland and the Czech Republic, increased their exports to the EU12 after joining the $\mathrm{EU}$ (and the internal market of the EU).

Table 1

Biggest exporters to the EU12 in 1990 and 2009

\begin{tabular}{|l|c|l|c|}
\hline $\begin{array}{l}\text { Biggest exporters } \\
\text { in 1990 }\end{array}$ & $\begin{array}{c}\text { Share of exports } \\
\text { in 1990 (\%) }\end{array}$ & $\begin{array}{l}\text { Biggest exporters } \\
\text { in 2009 }\end{array}$ & $\begin{array}{c}\text { Share of exports } \\
\text { in 2009 (\%) }\end{array}$ \\
\hline United States & $18.2 \%$ & China & $14.5 \%$ \\
\hline Japan & $10.4 \%$ & United States & $10.7 \%$ \\
\hline Switzerland & $7.1 \%$ & Russia & $5.2 \%$ \\
\hline Sweden & $5.7 \%$ & Switzerland & $4.9 \%$ \\
\hline Austria & $4.7 \%$ & Poland & $4.2 \%$ \\
\hline Norway & $3.5 \%$ & Japan & $3.9 \%$ \\
\hline Soviet Union & $3.1 \%$ & Austria & $3.8 \%$ \\
\hline China & $2.4 \%$ & Norway & $3.6 \%$ \\
\hline Finland & $2.4 \%$ & Czech Republic & $3.5 \%$ \\
\hline Canada & $2.1 \%$ & Sweden & $3.4 \%$ \\
\hline
\end{tabular}

Source: Eurostat Comext Database, 2011. 
As we would expect, primary commodities have the lowest rankings for PRODY within the 68 product groups (Table 2). In general, primary commodities are the main good exported by the poorest countries. The highest PRODY was calculated for the most sophisticated products. This is in accordance with the traditional theory of comparative advantage.

\section{Table 2}

Product classes with highest and lowest PRODY

\begin{tabular}{|l|l|}
\hline Lowest Prody* & Highest Prody* \\
\hline $\begin{array}{l}\text { COFFEE, TEA, COCOA, SPICES, AND } \\
\text { MANUFACTURES THEREOF }\end{array}$ & $\begin{array}{l}\text { PHOTOGRAPHIC APPARATUS, EQUIPMENT } \\
\text { AND SUPPLIES AND OPTICAL GOODS, } \\
\text { N.E.S.; WATCHES AND CLOCKS }\end{array}$ \\
\hline TOBACCO AND TOBACCO MANUFACTURES & METALWORKING MACHINERY \\
\hline $\begin{array}{l}\text { FIXED VEGETABLE FATS AND OILS, CRUDE, } \\
\text { REFINED OR FRACTIONATED }\end{array}$ & $\begin{array}{l}\text { MEDICINAL AND PHARMACEUTICAL } \\
\text { PRODUCTS }\end{array}$ \\
\hline $\begin{array}{l}\text { TEXTILE FIBRES (OTHER THAN WOOL TOPS } \\
\text { AND OTHER COMBED WOOL) AND THEIR } \\
\text { WASTES }\end{array}$ & $\begin{array}{l}\text { PAPER, PAPERBOARD AND ARTICLES OF } \\
\text { PAPER PULP, OF PAPER OR OF PAPERBOARD }\end{array}$ \\
\hline $\begin{array}{l}\text { CRUDE ANIMAL AND VEGETABLE } \\
\text { MATERIALS, N.E.S.. }\end{array}$ & ELECTRIC CURRENT \\
\hline
\end{tabular}

Source: Eurostat Comext Database, 2011.

* Calculation based on average rankings for 1990, 1995, 2000, 2005 and 2009

During the observed period, some product groups changed their positions in the "sophistication hierarchy". This can be affected by the changes in market prices, especially in the case of gas, and by the Common Agricultural Policy (CAP) and Trade Policy of the EU. The CAP and its customs policy restrict imports to the EU. With the enlargement of the EU, new members with relatively high GDP can now export agricultural products to the EU, which can increase the PRODY index. For example, the product group Feeding stuff for animals moved substantially up the quality ladder.

Table 3

Descriptive statistics of EXPY

\begin{tabular}{|l|c|c|c|c|c|}
\hline Year & Observation & Mean & Sd & Min & Max \\
\hline 1990 & 156 & 7767 & 3297 & 2448 & 19859 \\
\hline 1995 & 178 & 8282 & 3635 & 2924 & 18473 \\
\hline 2000 & 179 & 9290 & 3733 & 3106 & 18088 \\
\hline 2005 & 180 & 11027 & 4136 & 3118 & 26061 \\
\hline 2009 & 181 & 12774 & 6294 & 2846 & 44211 \\
\hline
\end{tabular}

Between the years 1990 and 2009, the maximum EXPY grew significantly, whereas the lowest index remained relatively stable. The highest EXPY index was calculated for 
Qatar. The reason is that gas is a prevalent good exported to the states of the EU12 from Qatar and the prices of gas grew significantly in the observed period.

Some countries changed their positions. Argentina, South Africa, Egypt", and India improved their EXPY scores, whereas Saudi Arabia, Pakistan, Morocco and Iraq exhibit the opposite direction. In the case of India, the position is probably underestimated since the EXPY only covers trade in manufacturing and not in services, where India has experienced a boom. There are also big changes in the positions among many small countries and islands whose exports to the EU12 are very low and deviate from year to year. In this case, lack of diversification of exports can change the EXPY significantly.

The lowest EXPY scores are mainly among the least developed African countries. The exports from these countries to the EU12 are very small and contain mostly primary commodities with the lowest PRODY scores. The most sophisticated exporters are traditional technological leaders like Japan, Switzeland, Sweden or the United States, and many small economies whose GDP per capita in PPP is one of the highest - Liechtenstein, San Marino, Singapore and Qatar (see Table 4).

The EXPY calculations by Hausmann et al. (2007) and Kemeny (2011) were based on imports to the USA. Therefore, it is difficult to compare their EXPY scores with my results because many EU12 countries were among the countries with highest EXPY scores for the US. On the other hand, Switzerland ranked among the highest values and poor African countries reached the lowest EXPY scores.

\section{Table 4}

Selected countries with the highest and lowest EXPY

\begin{tabular}{|l|c|l|c|}
\hline Smallest Expy* & $\begin{array}{c}\text { Share of Exports } \\
\text { in 2009 (\%) }\end{array}$ & Largest Expy* & $\begin{array}{c}\text { Share of Exports } \\
\text { in 2009 (\%) }\end{array}$ \\
\hline BURUNDI & 0 & JAPAN & 3,86 \\
\hline RWANDA & 0 & LIECHTENSTEIN & 0,05 \\
\hline MALAWI & 0,02 & SAN MARINO & 0 \\
\hline UGANDA & 0,03 & SINGAPORE & 1,01 \\
\hline PAPUA NEW GUINEA & 0,04 & SWITZERLAND & 4,89 \\
\hline COTE D'IVOIRE & 0,23 & QATAR & 0,25 \\
\hline ETHIOPIA & 0,03 & OMAN & 0,04 \\
\hline MONGOLIA & 0 & SWEDEN & 3,4 \\
\hline KENYA & 0,08 & FINLAND & 1,39 \\
\hline GUATEMALA & 0,03 & UNITED STATES & 10,69 \\
\hline
\end{tabular}

Source: Eurostat Comext Database, 2011, own calculations.

* Calculation based on average rankings for 1990, 1995, 2000, 2005 and 2009.

The high correlation coefficient between the GDP and EXPY confirms that rich countries export the same types of products that are exported by other rich countries, and the same is true for poor countries (see Table 5 and Fig. 1). Although the GDP is 
part of the EXPY calculation, further analysis by Hausmann et al. (2007) found that the EXPY is an independent force on economic growth.

\section{Table 5}

Regression of EXPY and GDP per capita

\begin{tabular}{|l|c|c|c|}
\hline Year & Number of observations & $\mathbf{R}^{2}$ & Root MSE \\
\hline 1990 & 156 & $0.4719^{\star}$ & 2403.9 \\
\hline 1995 & 178 & $0.4850^{\star}$ & 2615.8 \\
\hline 2000 & 179 & $0.3872^{\star}$ & 2941.9 \\
\hline 2005 & 180 & $0.4141^{\star}$ & 3181.1 \\
\hline 2009 & 181 & $0.4232^{\star}$ & 4973.2 \\
\hline
\end{tabular}

$* \mathrm{p}<0.05$

Source: Heston et al. (2011), own calculations.

\section{Figure 1}

Scatter graph for EXPY 09 and GDP09*

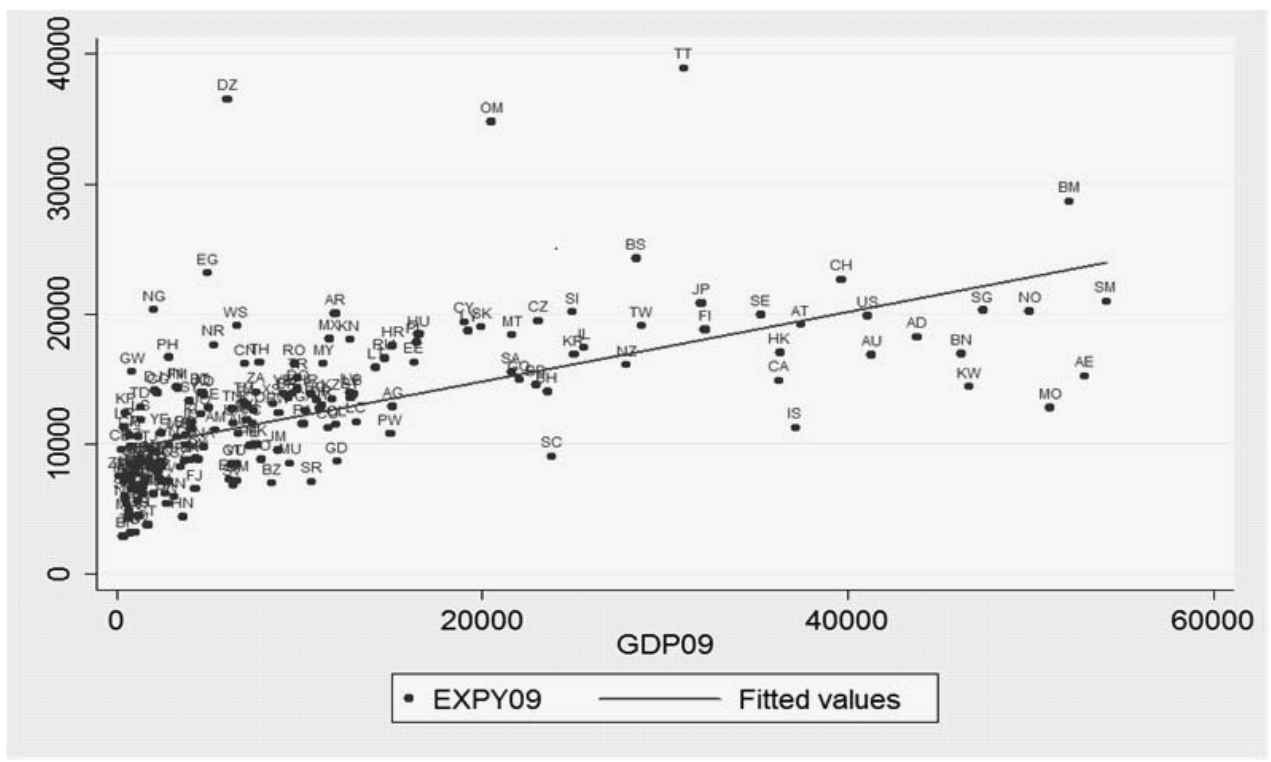

Source: Heston et al. (2011), own calculations.

* two outliers were left out of the chart (Lichtenstein and Qatar). 


\subsection{Results for China}

Despite the fact that the EXPY score for China rose from 13000 to 16000 (see Fig. 2 ), the ranking of China among other states went down from the $23^{\text {rd }}$ to the $44^{\text {th }}$ position. China is the biggest exporter of Office machines and automatic data-processing machines, electric machinery and Apparel and clothing; these product groups have the PRODY scores around the average. India seems to be doing better.

\section{Figure 2}

EXPY for selected countries from 1990 to 2009

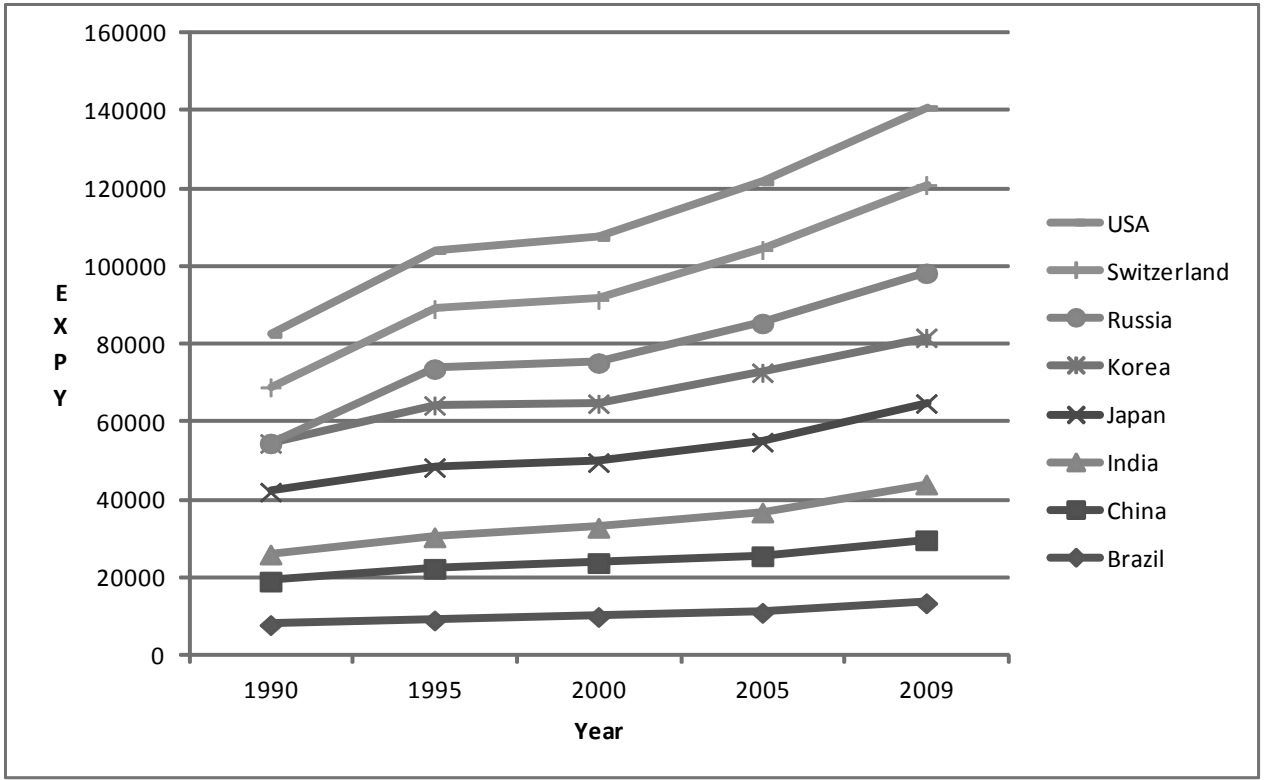

The EXPY calculated for China by Hausmann et al. (2007) between the years 1992 and 2003 had risen. Schott (2008), on the other hand, mentioned vertical differentiation, which means that even the same good can employ more sophisticated technologies and this should manifest in price differences. He found that even though China's export basket has increased markedly and now overlaps with that of high-income countries, China's relative export prices are significantly lower and have decreased over the last ten years.

Kemeny (2011) also found that the technological upgrading in China between 1972 and 2001 does not significantly outdo its income level. Kemeny (2011) used a price unit index and calculated TECH scores for each country. The TECH for China revealed that the growth in the TECH came from the fact that China started to produce more sophisticated goods with higher PRODY scores, whereas the quality of its goods (based on unit price comparisons) was downgrading. Amiti and Freund (2007) found that between 1997 and 2005, average prices of exports from China to the US fell by $1.6 \%$ per year whilst the average prices of the same products exported to the US from other 
countries increased on average by $0.7 \%$ by year. Although lower prices can indicate lower quality, China is often accused of manipulating the value of the yuan in order to give a competitive advantage to Chinese exporters. Prior to the 2005 revaluation, economists had argued that the yuan was undervalued by $15-40 \%$ (Forex Blog online, 2001). The undervaluation of the yuan could make the "quality" of the goods exported from China seemingly lower than they are in fact. On the other hand, if Chinese goods were sold at higher prices, they could not compete on the world markets because of their lower quality. Estimating China's technological capacities is even more difficult when we consider the huge regional differences within China.

Some studies found that the sophistication level of Chinese exports is higher than would correspond to its income level (Hausmann et al., 2007; Rodrik, 2006). Nevertheless, it could be a result of foreign-owned TNCs who export from China. Additionally, processing trade (sophisticated intermediate goods are imported to China and assembled as final goods for exporting) may have played a role. The calculation is based on the assumption that the exporting country produced the good from start to end. $\mathrm{Xu}$ and $\mathrm{Lu}$ (2009) focused on the role of foreign firms in the determination of China's export sophistication and estimated that there is increasing presence of wholly owned foreign firms. They contributed 63\% to China's rising export structure sophistication between 2000 and 2005. Even though the share of processing exports in total exports declined during the observed period, they estimate that this trend contributed $25 \%$ to China's rising export structure sophistication. Koopman et al. (2008) estimated that processing exports account for more than 50\% of China's exports. Amiti and Freund (2007) conclude that when processing trade is accounted for, the labour intensity of China's exports remains the same between 1997 and 2005.

Using EU12 data has many limitations. The USA has a huge market, clearer trade rules and borders only with Mexico and Canada. In contrast, the EU12 has many small neighbouring countries with open economies. The CAP and the common trade policy of the EU, including the antidumping policy, can influence the imports to the EU. During the observed period, another 15 countries became the members of the EU and thus joined the EU CAP and its internal market. Accession to the EU is connected with the abolishment of most of the taxes on imports ${ }^{9}$ and quantitative restrictions. Thus, trade relations with the EU are intensified. Three EFTA member countries are on the EU internal market. The EU also has many trade agreements with third countries. The common agricultural policy and trade policy of the EU can thus significantly affect the type and volume of goods imported to the EU.

\section{Conclusion}

The aim of this paper was to evaluate China's technological and innovation capabilities. Apart from being the workshop of the world, China is also trying to become a technology leader. This fact worries developed countries, which were traditionally the centres of innovations and new technologies. The views on China's potential techno-

9 The average customs for industrial products is $4 \%$, for agricultural products $18 \%$. 
logical leadership differ significantly. Some researchers think that China does not have sufficient capabilities whereas others consider China's technological leadership to be a question of the near future. Measuring technology and innovations is notoriously problematic, since it is difficult to observe it in the economy. One of the methods of assessing it is to measure the technological sophistication of a country's exports. In this paper, the technological sophistication of Chinese exports to the EU12 based on the calculation of the EXPY proposed by Hausmann et al. (2007) was used as a measure.

Since labour costs in China are relatively low, it is expected that it will produce and export labour-intensive products like clothes whereas capital-intensive countries will specialise on products such as pharmaceuticals. The EXPY calculation for China based on the exports to the EU12 between 1990 and 2009 indicates that the sophistication of Chinese products in comparison to other countries' has dropped. In contrast, Hausman et al. (2007) found that the sophistication of Chinese exports was rising. Kemeny (2011) came to a conclusion similar to mine: that China's technological capabilities correspond with its income-level. Thus, China does not seem to threaten the technological position of the developed countries, especially the EU, yet.

Bresnitz and Murphree (2011) believe that new interdependencies stemming from "international decomposition of productive activities [challenge] the core assumption that states must at some point master novel-product innovation if they are to sustain growth". According to them, China can gradually improve its position thanks to incremental product and process innovations without excelling in breakthrough innovations. If they are right, China can still be a threat to the developed countries. On the other hand, the results indicate that the incremental innovations have been accomplished among products with an intermediate level of sophistication. In addition, if China and the USA keep investing in R\&D at the same rates, it will take China 20 years to reach the US level.

This paper is only a preliminary study; it raised interesting questions and requirements for further research. Firstly, more detailed product classification is required in order to capture the differences at the product level as well as the price unit indicator. Although the results of calculations with and without the price index are highly correlated, in the case of China, using the price might yield interesting results. While the export basket of China to the US overlaps with that of developed countries, the prices of China's products are considerably lower (Schott, 2008) and the same situation is expected for the EU. Secondly, more attention has to be paid to GPN and processing exports and the role of the Yuan appreciation. Thirdly, trade policies of particular countries and EU policies (CAP, trade) should be evaluated in more detail with respect to the trade volume. Using the EU27 countries for the EXPY calculation should be considered. Fourthly, estimating China's technological capacities is even more difficult when we consider the huge regional differences within China. Therefore, data on regional Chinese exports might be of great interest. 


\section{References}

AGHION, P.; HOWITT, P. A model of growth through creative destruction. Econometrica. 1992, vol. 60, no. 2, s. 323-351.

ALTENBURGH, T.; SCHMITZ, H.; STAMM, A. Breakthrough? China's and India's Transition from Production to Innovation. World Development. 2008, vol. 36, no. 2, s. 325-344.

AMITI, M.; FREUND, C. An anatomy of China's export growth. Global Implications of China's Trade, Investment and Growth Conference, IMF Research Department, 6 April 2008.

BAUMOL, W. J.; BLACKMAN, S. A. B.; WOLFF, E. N. Productivity and American leadership: the long view. Cambridge, MA : MIT Press, 1989. 407 s. ISBN 978-0262521635.

BRESNITZ, D.; MURPHREE, M. Run of the red queen. New Haven and London : Yale University Press, 2011. 278 s. ISBN 978-0300152715.

CAO, C. Zhongguancun and China's High-Tech Parks in Transition: "Growing Pains" or "Premature Senility"? Asian Survey. 2004, vol. 44, no. 5, s. 647-688.

COE, N. M.; DICKEN, P.; HESS, M. Global production networks: realizing the potential. Journal of Economic Geography. 2008, vol. 8, no. 3,s. 271-295.

COMIN, D.; HOBIJN, B.; ROVITO, E. Five facts you need to know about technology diffusion [Working Paper No. 11928]. Cambridge, MA : NBER, 2006. http://www.nber.org/papers/w11928.

DICKEN, P. Global Shift, Sixth Edition: Mapping the Changing Contours of the World Economy. New York and London : Guilford Press, 2011. 607 s. ISBN 978-1609180065.

EUROSTAT. Comext Database - External trade data. [cit. 2011-08-25]. http://epp.eurostat.ec.europa. eu/newxtweb.

FOREX BLOG - online. The Diminished Case for Chinese Yuan Appreciation. 5. 3. 2011 [cit. 2011-0930]. www.forexblog.org/2011/05/the-diminished-case-for-chinese-yuan-appreciation.html.

FREEMAN, R. B. Does Globalization of the Scientific/Engineering Workforce Threaten U.S. Economic Leadership? [Working Paper No. 11457]. Cambridgem MA : NBER, 2005. www.nber.org/papers/ w11457.

GERTLER, S. T. Tacit knowledge in production systems: how important is geography? In POLANSKE, R. K. The economic geography of innovations. Cambridge : University Press, 2007. 384 s. ISBN 9780521689533.

GRILICHES, Z. Issues in assessing the contribution of research and development to productivity growth. Bell Journal of Economics. 1979, vol. 10, no. 1, s. 92-116.

HALL, R. E.; JONES, C. I. Why do some countries produce so much more output per worker than others? The Quarterly Journal of Economics. 1999, vol. 114, no. 1, s. 83-116.

HAUSMANN, R., HWANG, J.; RODRIK, D. What you export matters. Journal of Economic Growth. 2007, vol. 12, no. 1, s. 1-25.

HESTON, A.; SUMMERS, R.; ATEN, B. Penn World Table Version 7.0, Center for International Comparisons of Production, Income and Prices at the University of Pennsylvania, May 2011.

HUMMELS, D.; ISCHII, L.; YI, K. The nature and growth of vertical specialization in world trade. Journal of International Economics. 2001, vol. 54, no. 1, s. 75-96.

CHINESE GOVERNMENT'S OFFICIAL WEB PORTAL. Guidelines on building innovation-oriented country issued. 9. 2. 2006 [cit. 2012-2-11]. http://english.gov.cn/2006-02/09/content_183733.htm.

JAFFE, A. B.; TRAJTENBERG, M.; HENDERSON, R. Geographic localization of knowledge spillovers as evidenced by patent citations. The Quarterly Journal of Economics. 1993, vol. 108, no. 3, s. $577-598$.

KEMENY, T. Are Technology Gaps Growing or Shrinking in the Age of Globalization? Journal of Economic Geography. 2011, vol. 11, no. 1, s. 1-35. 
KOOPMAN, R.; WANG, Z.; WEI, S. How Much of Chinese Exports is Really Made In China? Assessing Domestic Value-Added [Working Paper No. 14109]. Cambridge, MA : NBER, 2008. www.nber. org/papers/w14109.

LUNDVALL, B. National Systems of Innovation: Towards a Theory of Innovation and Interactive Learning. London : Pinter, 1992. 342 s. ISBN 978-1855670631.

McKINSEY. Addressing China's Looming Talent Shortage [cit. 2011-05-05]. www.mckinsey.com/mgi/ reports/pdfs/China_talent/ChinaPerspective.pdf.

OECD. Productivity Manual: A Guide to the Measurement of Industry-Level and Aggregate Productivity Growth. Paris : OECD, 2001. 156 s. ISBN 978-9264187375.

OECD. Frascati Manual: Proposed standard practice for surveys on research and experimental development. Paris : OECD, 2002. 256 s. ISBN 978-9264199033.

OECD. The Measurement of Scientific and Technological Activities Oslo Manual: Guidelines for Collecting and Interpreting Innovation Data, 3rd Edition. Paris : OECD, 2006. 164 s. ISBN 9789264013087.

OECD. Innovation and Growth: Chasing a Moving Frontier. Paris : OECD, 2009.266 s. ISBN 9789264073968.

OECD. OECD Science, Technology and Industry Outlook. Paris : OECD, 2010. 280 s. ISBN 9789264084674.

PATEL, P.; PAVITT, K. Large Firms in the Production of the World's Technology: An Important Case of „Non-Globalisation“. Journal of International Business Studies. 1991, vol. 22, no. 1, s. 1-21.

PORTER, A.; NEWMAN, N. ;ROESSNER, D.; JOHNSON, D.; JIN, X. International high tech competitiveness: Does China rank \#1? Technology Analysis and Strategic Management. 2009, vol. 21, no. 2, s. $179-193$.

RODRIK, D. What's so special about China's exports? [Working Paper No. 11947]. Cambridge, MA : NBER, 2006. www.nber.org/papers/w11947 .

ROMER, P. EndogenousTechnologicalChange [Working Paper No. 9762]. Cambridge, MA : NBER, 1991. www.nber.org/papers/w9762.

ROSENBERG, N. Inside the Black Box: Technology and Economics. Cambridge : University Press, 1982. 320 s. ISBN 978-0521273671.

SAXENIAN, A. Regional advantage: culture and competition in Silicon Valley and Route 128. Harvard : University Press, 1996. 240 s. ISBN 978-0674753402.

SAXENIAN, A. Brain circulation and regional innovation: the Silicon Valley-Hsichu-Shanghai triangle. In POLANSKE, R. K. The economic geography of innovations. Cambridge : University Press, 2007. 384 s. ISBN 978-0521689533.

SCOTT, P. K. The relative sophistication of Chinese exports. Economic Policy. 2008, vol. 23, no. 53, S. 5-49.

SEGAL, A. Digital dragon: high-technology enterprises in China. Ithaca, N.Y. : Cornell University Press, 2003. 208 s. ISBN 978-0801476365.

SCHUMPETER, J. A. Capitalism, socialism, and democracy. 3rd ed. London : Harper Perennial Modern Classics, 1947. 464 s. ISBN 978-0061561610.

STORPER, M. Why do regions develop and change? The challenge for geography and economics. Journal of Economic Geography. 2011, vol. 11, no. 2, s. 333-346.

UNCTAD. World Investment Report. Transnational Corporations and the Internationalization of R\&D. New York and Geneva : United Nations, 2005. 368 s. ISBN 978-9211126679.

$\mathrm{XU}, \mathrm{B}$. Measuring the technology content of China's exports. Manuscript, China Europe International Business School (CEIBS). June 2006 [cit. 2012-2-11]. www.econ.hit-u.ac.jp/ trade/apts/2006/ pdf/Bin_Xu.pdf. 
XU, B.; LU, J. Foreign direct investment, processing trade, and the sophistication of China's exports. China Economic Review. 2009, vol. 20, no. 3, s. 425-439.

ZHOU, Y.; SUN, Y., WEI, D.; LIN, C. De-centering 'spatial fix' - patterns of territorialization and regional technological dynamism of ICT hubs in China. Journal of Economic Geography. 2010, vol. 11, no. 1 , s. $119-150$.

\title{
IS CHINA CATCHING UP? TECHNOLOGICAL SOPHISTICATION OF CHINESE EXPORTS TO EUROPEAN UNION
}

\begin{abstract}
Increases in the technological sophistication of some emerging economies, linked, in part, to shifts in the distribution of innovation activities from developed to emerging economies has attracted a lot of attention. Whether emerging economies will catch up with developed regions in terms of innovation and technology remains an open question. Various methods can be used to measure the technological capacity of an economy, though most suffer from a number of significant problems. In this paper, I present a relatively new measure of a country's technological sophistication based upon the goods that it exports. The empirical analysis focuses on exports to the European Union over the period 1990-2009. Special attention is paid to China, which has made a huge progress in technology and innovations in the past years. Based on this analysis, China's technological capabilities correspond with its income level and thus China does not seem to threaten the technological position of the EU yet.
\end{abstract}

Keywords: technological upgrading, R\&D, Chinese exports, China

\section{JEL Classification: FO}

